\title{
The Role of Formed Microorganism in Sludge on Processing of Wastewater Treatment
}

\author{
Ahmed Aidan Al-Hussieny, Saba Hussein Obeid, Noor Nihad Baqer, Sajida Frhan Hussain and Ayad Gheni \\ Mohammed \\ Ministry of Science and Technology -Directorate of water and Environment, Baghdad 10001, Iraq
}

Received: January 4, 2015 / Accepted: March 31, 2015 / Published: March 31, 2015.

\begin{abstract}
Several microorganisms such as bacteria, fungi, Protozoa, Rotifera, cystic amoeba and algae diagnosed in activated sludge aerobic (Rustumiya treatment plant) and anaerobic reactor. Results have shown a reduction in the turbidity rates when using activated sludge at Rustumiya plant of 76.3 to 2.653 NTU in pre-treatment and final tank respectively, also COD (chemical oxygen demand) amount reduced from 427.263 to $82 \mathrm{mg} / \mathrm{L}$ respectively. In addition, concentrations of phosphates and nitrates decreased from 12.083 to $8.426 \mathrm{mg} / \mathrm{L}$ and 3.59 to $2.43 \mathrm{mg} / \mathrm{L}$ respectively, by removing $30.2 \%$ and $32.3 \%$ respectively of the final tank. The ratio of ammonia removing was $89.6 \%$ for ammonia, reducing process from 1358 to $140 \mathrm{mg} / \mathrm{L}$. Furthermore, sulfates concentration decreased from 30.883 to $23.337 \mathrm{mg} / \mathrm{L}$. However, the system in the anaerobic reactor depends on non-aerated activated sludge. Results show turbidity reduced from 12.5 to 2 NTU in pre-treatment and final tank respectively, also the COD mount reduced from 191 to $130 \mathrm{mg} / \mathrm{L}$, the percentage removal of $31.9 \%$. In addition phosphates, nitrates and sulfates concentrations were decreased by using activated sludge from 17.15 to $8.15,1.2$ to 0.1 and 28 to $9.2 \mathrm{mg} / \mathrm{L}$ respectively. The ammonia concentration has reduced from 1.2 to $0.1 \mathrm{mg} / \mathrm{L}$ where at a removal percentage of $90.9 \%$.
\end{abstract}

Key words: Microorganism, sludge, wastewater, removing, chemical oxygen demand, protozoa, bacteria, algae.

\section{Introduction}

Different treatment units as primary settling tanks, trickling filters, activated sludge plants ect give out sludge. Sludge from other units as mentioned above contains putrescible organic substances, pathogenic organisms ect which are unsafe to public health. The quantity of produced sludge is huge and its handling and disposal become a big task [1]. In addition, wastewater contains inorganic chemical compounds from waters supplies and many complex organic material which are derived from faces, urine and other organic wastes. Wastewater is normally alkaline when fresh but tends to be acidic as it becomes state [2]. By stabilization it is meant that organic matter has been broken down by bacterial action to simple

Corresponding author: Ahmed Aidan Al-Hussieny, B.Sc. Biology, research field: processing technology of environment and water. E-mail: ahmed.edan85@yahoo.com, ahmed.edan85@gmail.com. inorganic substance. Anaerobic bacteria grow and liberate energy in the absence of free oxygen and obtain it from various compounds which are to break down. In anaerobic stabilization, however, reaction is slow and this process gives off unpleasant odors [3]. Aerobic action takes place when free oxygen is available for bacteria, the oxygen may be available from atmosphere or sewage. On the other hand, facultative type of organisms is those which can thrive and continue their life activities both in presence and absence of oxygen. If oxygen is available they become aerobic. All above groups are helpful in the stabilization of sewage and known as Saprophytes [4]. In the liquid layers of the pound, algae begin to grow under favorable conditions, the algae utilize the carbon dioxide in the sewage for photosynthesis during day light hours liberating oxygen which maintains aerobic condition in the upper layers of the pound, algae growth convert solar energy to chemical 
energy in organic form. Empirical studies show that about 6 percent of visible light energy converted to algal energy [5]. The aerobic bacteria grouped upon their role in flock formation. The free-swimming bacteria are floating in the wastewater among activated sludge flocks, if they are present in huge number they may contribute to high effluent BOD5 (biological oxygen demand). The flock forming bacteria are attached to each other and constitute well settling flock-like biomass, which can be separated easily from the liquid phase in the final clarifier. Filamentous bacteria can be useful, because they can work as skeleton for flocks. On the other hand, if lots of filamentous bacteria are present in the sludge, they often cause bulking and foaming problems [6, 7]. Protozoa, which feed on bacteria, are also found active. Higher multi-cellular animal forms, known as metazoan, like nematodes, rotifers, annelid worms feed upon the organic slime and keep the bed porous, thus make the bed fit for re-use after certain interval. The aim of the present study was to screen the role of microorganisms in the activated sludge digestion.

\section{Material and Methods}

\subsection{Isolation and Diagnosis of Bacteria}

Depending on Gerardi [8], the samples were diluted to 3rd dilution, 2nd and 3rd dilution were examined by using nutritious agar medium. These plates serve as an incubator at $37{ }^{\circ} \mathrm{C}$ for $24 \mathrm{~h}$. At the end of the incubation period, the appearance of bacterial colonies was gram stained for microscopic morphology. Then colonies were transferred to the differential medium follow on Manitol salt agar, Pseudomonas agar, McConkie agar, Gauze agar and Shigella Salmonella.

\subsection{Diagnosis of Zooplankton}

Zooplankton is found in sewage. $1 \mathrm{~mL}$ of sample of zooplankton was examined by light microscope, using depression slide under magnification of $50 \times$ power compound microscope according to Kudo [9].

\subsection{Diagnosis of Algae}

The non-diatom algae were isolated and diagnosed by microscopically examination, depending on the number of references to classify of non-diatom algae $[10-12,13]$.

\subsection{Isolation and Identification of Yeast}

Yeasts were isolated and diagnosed from Al-Rustumiya station by using media consist of (potato dextrose agar and antibiotic chloramphenicol 1 $\mathrm{mg} / \mathrm{L}$ ). $1 \mathrm{~mL}$ of sample (every sample) was mixed with media in plate $(9 \mathrm{~cm}$ diameter) three replicate for every sample, these were incubated at $25-27^{\circ} \mathrm{C}$ for 48 $\mathrm{h}$ according to Kurtzmar [14]. The isolate yeasts diagnosed by using biochemical testes according to Bennet, Kurtzman, Shrestha and Bennet [15, 16-18].

\subsection{Physiochemical Screening}

Physiochemical factors such as $\mathrm{pH}, \mathrm{COD}, \mathrm{SO} 4$, NO3, TSS, PO4 and Turbidity measured, according to standard method of analysis $[19,20]$.

\section{Result}

\subsection{Wastewater Treatment Plants and Anaerobic Reactor}

Characterization of activated sludge reveals the ledge of spatiality in sewage wastewater treatment by using anaerobic activated sludge, at a Ministry of Science and Technology, where results showed reduced turbidity by using activated sludge in processing of plant stages entry tank, treatment tank, sludge tank and final tank. Turbidity reduced to 12.5 , 9.6, 29.7 and 2 NTU respectively. COD reduced to $191,181,230$ and $130 \mathrm{mg} / \mathrm{L}$ respectively. In addition, phosphate concentrations reduced to $17.15,19.45,72.4$ and $8.14 \mathrm{mg} / \mathrm{L}$ respectively. The nitrate concentrations reduced to $1.2,0.2,0.1$ and $0.1 \mathrm{mg} / \mathrm{L}$ respectively. As to ammonia, concentrations reached to $1.1,1.6,2.3$ and $0.1 \mathrm{mg} / \mathrm{L}$ respectively; whereas absorption reached to $0.218,0.238,0.945$ and $0.002 \mathrm{~nm}$ 
respectively, the sulfate concentrations reached to 28 , 12,26 and $9.2 \mathrm{mg} / \mathrm{L}$ respectively, acidity $\mathrm{pH}$ of stages plant 7.2, 7.8, 7.6 and 6.5 respectively (Table 1).

As to TSS (total suspended solids) matter, concentrations reached plant stages to $990,1020,1400$ and $860 \mathrm{mg} / \mathrm{L}$ respectively and Fig. 1.

\section{2 Russtamyia Treatment Plant}

Characterization of wastewater treatment and the activated sludge of Russtamyia station sewage wastewater treatment by using activated sludge aerobic processing. Turbidity reduced by using activated sludge during processing stages of plant entry tank, primary tank, secondary tank, sludge tank and final tank 76.3, 16.03, 4993.3, 11333.3 and 2.65 NTU respectively. COD was reduced to $427.263,8.25$, $371,523.75$ and $82 \mathrm{mg} / \mathrm{L}$, respectively.

Phosphate concentrations reduced to $12.083,6.366$,
22.97, 31.455 and $8.426 \mathrm{mg} / \mathrm{L}$, respectively. Nitrate concentrations reduced to $3.59,1.75,1.17,2.86$ and $2.43 \mathrm{mg} / \mathrm{L}$, respectively. On the other hand, ammonia concentrations were reduced to $1358,280,518,532$ and $140 \mathrm{mg} / \mathrm{L}$ respectively; whereas absorption was reduced to $0.018,0.047,0.064,0.407$ and $0.027 \mathrm{~nm}$, respectively, sulfate concentrations were reduced to 30.883, 22.809, 18.234, 20.584 and $23.337 \mathrm{mg} / \mathrm{L}$ respectively, as acidity $\mathrm{pH}$ of plant stages $7.01,7.3$, 7.28, 7.02 and 7.5, respectively Table 2.

As to TSS matter concentrations of plant stage, they were reduced to $30,14100,1850,12000$ and $11 \mathrm{mg} / \mathrm{L}$ respectively and Fig. 2 .

Moreover, the Table 3 removal time of all chemical tests between Russtamyia plant treatment and anaerobic plant of final tank.

Biochemical tests of the isolated yeast from anaerobic reactor plant of sludge tank Table 4.

Table 1 Chemical test of anaerobic plant treatment.

\begin{tabular}{lllllllll}
\hline Plants & $\begin{array}{l}\text { Phosphate } \\
\mathrm{mg} / \mathrm{L}\end{array}$ & $\begin{array}{l}\text { Nitrate } \\
\mathrm{mg} / \mathrm{L}\end{array}$ & $\begin{array}{l}\text { Ammonia } \\
\mathrm{mg} / \mathrm{L}\end{array}$ & $\mathrm{pH}$ & $\begin{array}{l}\text { Absorption } \\
\mathrm{nm}\end{array}$ & $\begin{array}{l}\text { Turbidity } \\
\text { NTU }\end{array}$ & $\begin{array}{l}\text { Sulfate } \\
\mathrm{mg} / \mathrm{L}\end{array}$ & $\begin{array}{l}\text { COD } \\
\mathrm{mg} / \mathrm{L}\end{array}$ \\
\hline Basin tank & 17.15 & 1.2 & 1.1 & 7.2 & 0.218 & 12.5 & 28 & 191 \\
Treatment tank & 19.45 & 0.2 & 1.6 & 7.8 & 0.238 & 9.6 & 12 & 181 \\
Sludge tank & 72.4 & 0.1 & 2.3 & 7.6 & 0.945 & 29.7 & 26 & 230 \\
Final tank & 8.15 & 0.1 & 0.1 & 6.5 & 0.002 & 2 & 9.2 & 130 \\
\hline
\end{tabular}

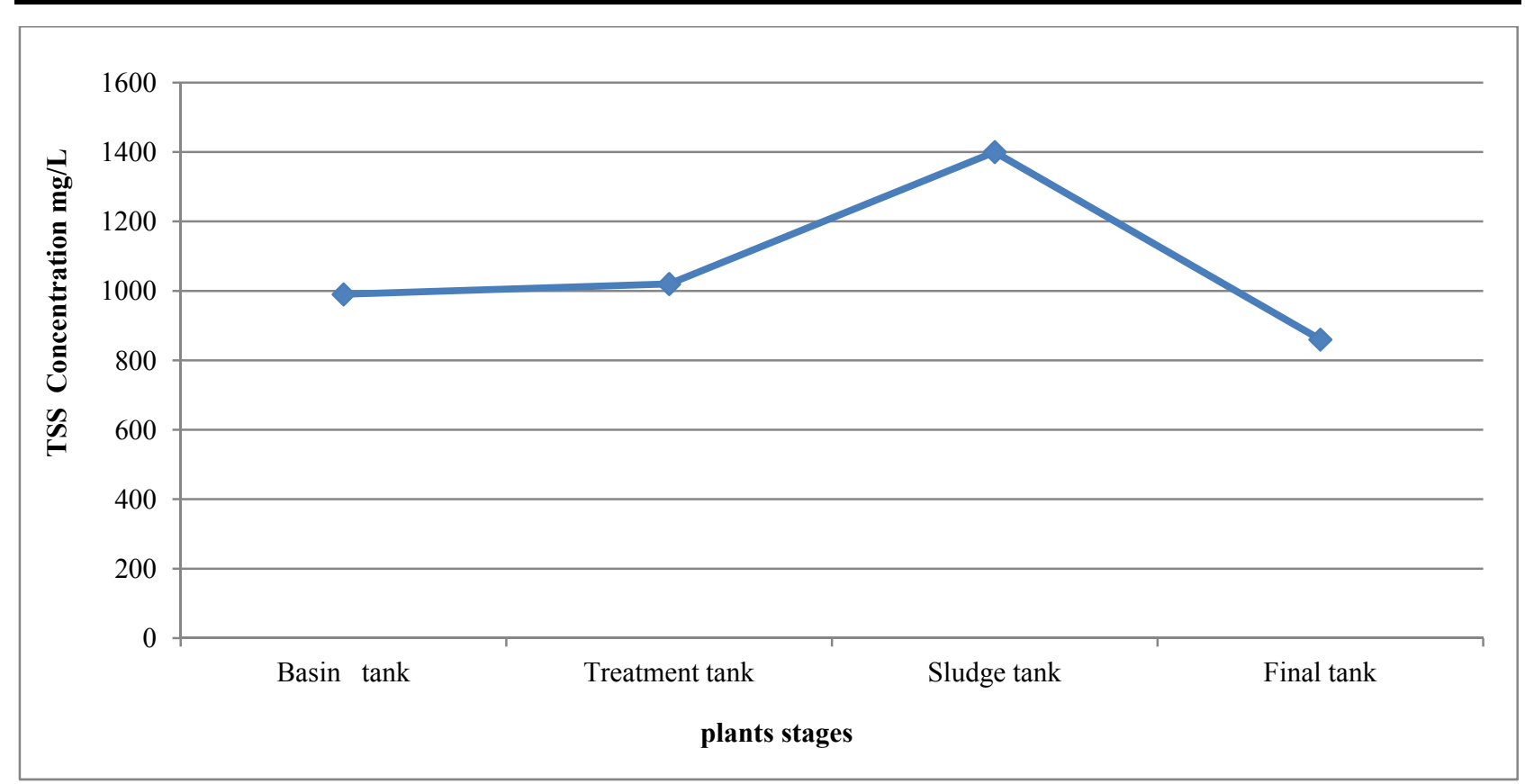

Fig. 1 TSS matter concentrations of anaerobic plant (TSS Concentration mg/L). 
Table 2 Chemical test of sample of Russtamyia treatment plant.

\begin{tabular}{llllllll}
\hline Plants & $\begin{array}{l}\text { Phosphate } \\
\mathrm{mg} / \mathrm{L}\end{array}$ & $\begin{array}{l}\text { Nitrate } \\
\mathrm{mg} / \mathrm{L}\end{array}$ & $\begin{array}{l}\text { Ammonia } \\
\mathrm{mg} / \mathrm{L}\end{array}$ & $\mathrm{pH}$ & $\begin{array}{l}\text { Absorption } \\
\mathrm{nm}\end{array}$ & $\begin{array}{l}\text { Sulfate } \\
\mathrm{mg} / \mathrm{L}\end{array}$ & $\begin{array}{l}\text { COD } \\
\mathrm{mg} / \mathrm{L}\end{array}$ \\
\hline Entry tank & 12.083 & 3.59 & 1358 & 7.01 & 0.018 & 30.883 & 427.263 \\
Primary tank & 6.366 & 1.75 & 280 & 7.3 & 0.047 & 22.809 & 8.25 \\
Secondary tank & 22.97 & 1.178 & 518 & 7.28 & 0.064 & 18.234 & 371 \\
Sludge tank & 31.455 & 2.86 & 532 & 7.02 & 0.407 & 20.584 & 523.75 \\
Final tank & 8.426 & 2.43 & 140 & 7.5 & 0.027 & 23.337 & 82 \\
\hline
\end{tabular}

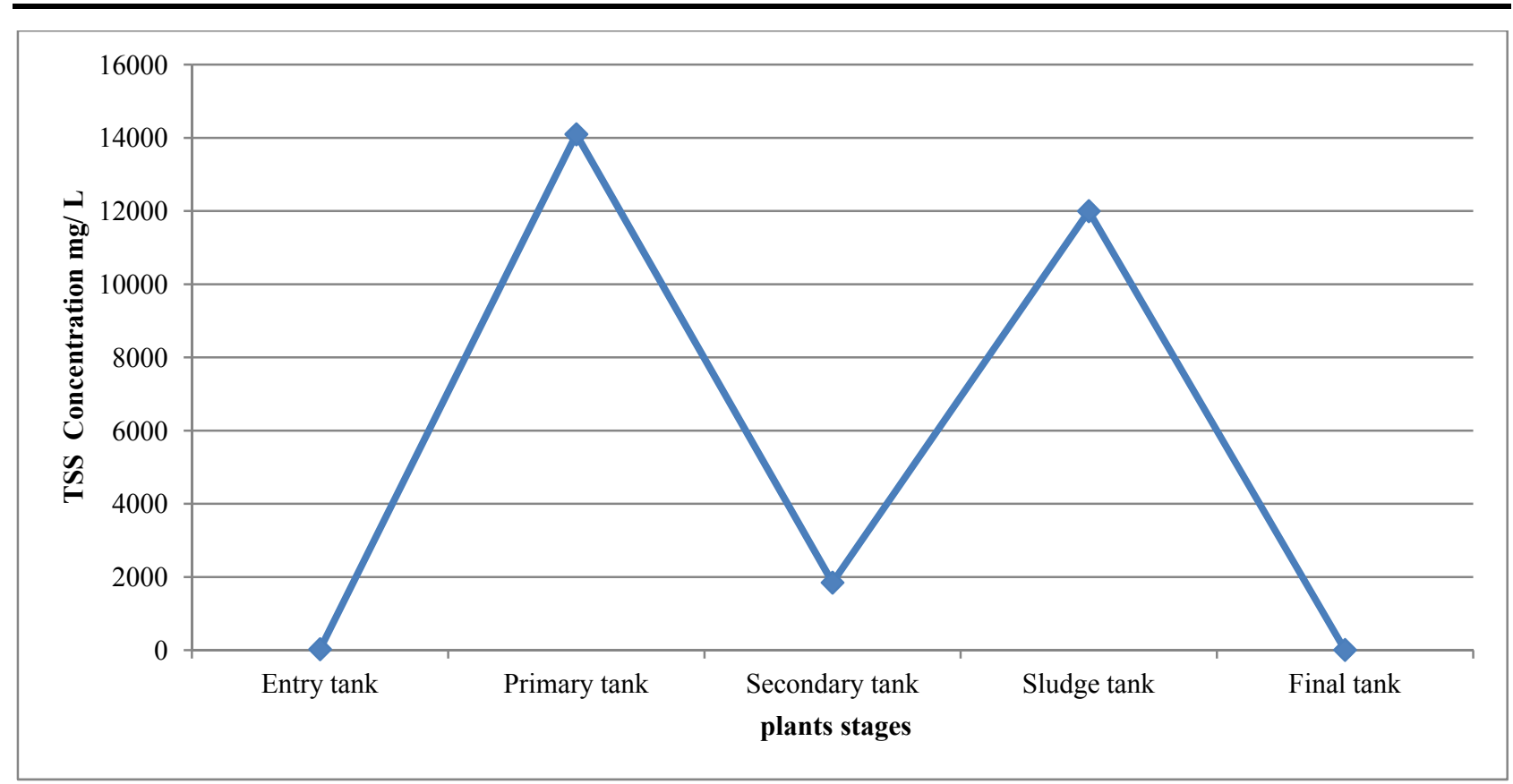

Fig. 2 TSS matter concentrations of Russtamyia treatment plant stages.

Table 3 Chemicals removal \% of final tank for Russtamyia and anaerobic reactor plants.

\begin{tabular}{lll}
\hline \multirow{2}{*}{\begin{tabular}{l} 
mg $/ \mathrm{L}$ \\
\cline { 2 - 3 }
\end{tabular}} & Russtamyia (\%) & plants \\
\hline COD & 69.2 & Reactor anaerobic (\%) \\
Sulfate & 24.4 & 31.9 \\
Phosphate & 30.2 & 67.1 \\
Nitrate & 32.3 & 52.4 \\
Ammonia & 89.6 & 91.6 \\
\hline
\end{tabular}

Table 4 Biochemical tests of isolated yeast.

\begin{tabular}{|c|c|c|c|c|c|c|c|c|c|c|c|c|c|}
\hline \multirow{2}{*}{ Yeast species } & \multirow{2}{*}{1} & \multicolumn{11}{|c|}{ Sugar Assimilation } & \multirow{2}{*}{-13} \\
\hline & & 2 & 3 & 4 & 5 & 6 & 7 & 8 & 9 & 10 & 11 & 12 & \\
\hline Lipomyce sarxii & + & + & - & - & - & - & + & - & + & + & - & - & - \\
\hline Rhodotorula mucilaginosa & + & + & - & + & + & - & + & + & + & + & + & Weak & + \\
\hline
\end{tabular}



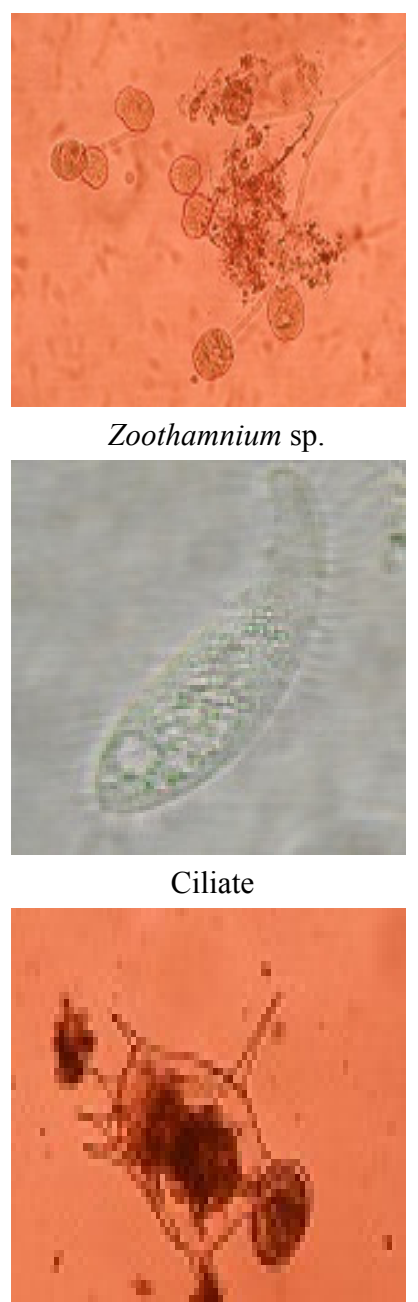

Brachionus calycifloru

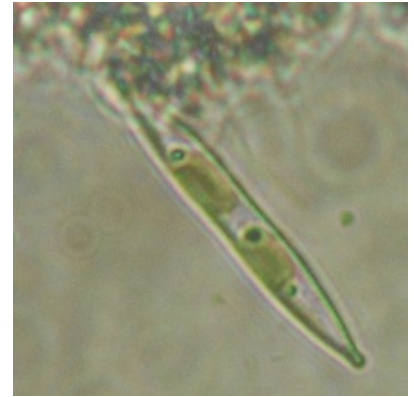

Nitzschia $\mathrm{sp.}$

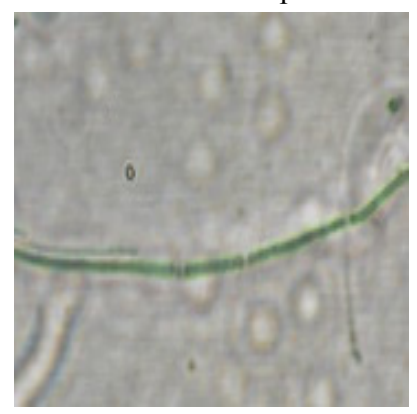

Oscillatoria $\mathrm{sp}$.

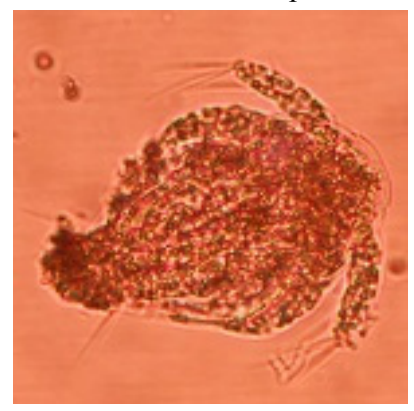

Cyclop

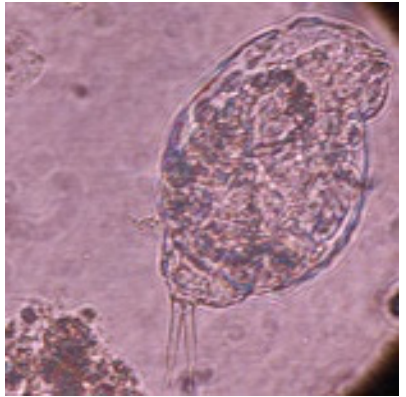

Lecaneluna

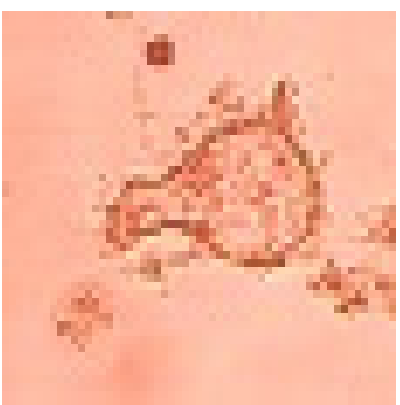

Nebela sp.

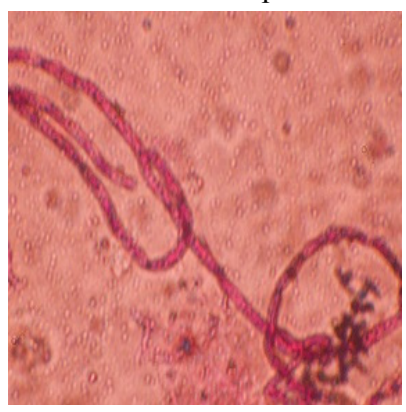

Streptomyces

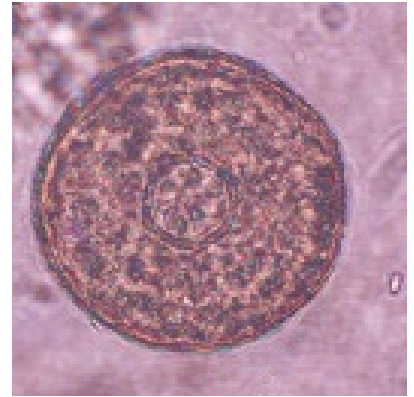

Arcella discios

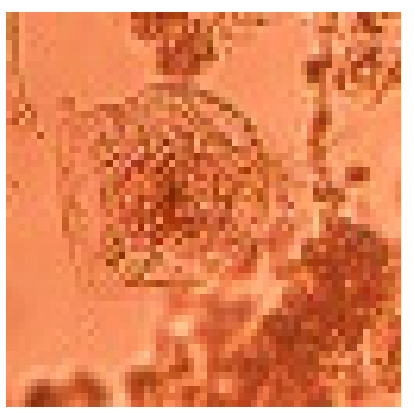

ecane sp.

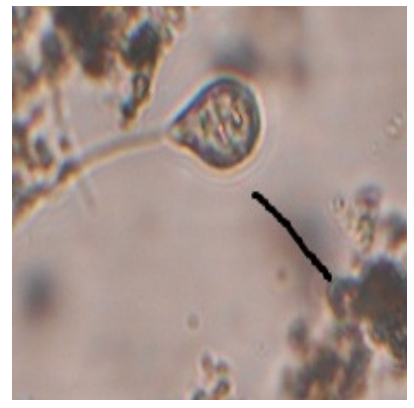

vorticella $\mathrm{sp}$.

Fig. 3 More important organisms were founded in sludge tank of reactor plant anaerobic.

A permanent species of bacteria was founded in the aerobic activated sludge like Filamentous bacteria such as Streptomyces sp. On the other hand, the non-filamentous bacteria such as Escherichia sp., Salmonella sp., Shigella, staphloccous aureus, the bacteria were founded in the anaerobic sludge such as Clostridium perfringens and Bacillus sp. While fungus such as Rhizopus stolonifer and Penicillium echinulatu, and the large numbers of zooplankton such as Arcella discoides, Lecane sp., Vorticella sp., Ciliata, Philodania, Nebela sp. and Nematoda sp., and the important algae were founded such as Oscillatoria limnetica, Spirogyra borgeana, Lyngbya digueti, Microcystes flos-aquae, Navicula cryptocephala and Nitzschia acicularis (Fig. 3). All these organisms were identified depending on which played on important role in the treatment process $[8-12,15,21]$.

\section{Discussion}

Activated sludge consists of approximately $95 \%$ bacteria and $5 \%$ higher organisms such as protozoa, metazoan, fungi, rotifers, etc. These microorganisms have a role in the activated sludge process to treat various types of wastes [22]. Bacteria are responsible for the biological oxidation of organic substrates, nitrification of ammonia, denitrification of nitrate and accumulation of phosphorous and they constitute the major component of activated sludge [23]. Furthermore, bacteria, may be divided into groups according to their response to free molecular oxygen. 
These groups are strict aerobes, facultative anaerobes, and anaerobes. In the case of availability of oxygen, activate aerobic bacteria and decomposition of organic materials to $\mathrm{CO}_{2}$, water, nitrate, and energy. But if it is not available oxygen activate anaerobic bacteria and decomposition of organic materials to energy, water, $\mathrm{H}_{2} \mathrm{~S}$, and ammonia [8]. More than $80 \%$ of biological waste water plants are based on the principle of activated sludge process, in which suspended bacteria oxidize the carbonaceous and nitrogen compounds to produce an effluent that is in accordance with legal standards, and that corresponds to a minimal environmental impact [5]. The activated sludge flocks contain mostly bacterial cells as well as other microorganisms (Fungi, Rhizopoda, Flagellates, Ciliates, Rotifers) and inorganic and organic particles. That has a role in biological process [24], this result came consistent with Ghazy [25] has showed COD, BOD, TSS and ammonia decreased through stages of treatment process. The removal of these parameters during studied period ranged 86-95, 91-96, 90-94 and $71-85 \%$ respectively. Micro fauna, amoebae and flagellates appeared at low DO (dissolved oxygen) and high organic load, dominance of crawling and stalked ciliates affected efficiency of treatment. Rotifers count ranged from $1.3 \times 103$ to $9 \times 104$, indicating good sludge quality. Showed by Usharant [25] the efficiency of Pseudomonas sp. to phosphate removal to be maximum of $68 \%$ in synthetic phosphate wastewater with glucose carbon source followed by starch (66\%), sucrose (65\%) and lactose $(62 \%)$ after $72 \mathrm{~h}$ at neutral $\mathrm{pH}(7.0 \pm 2)$.

Awad and Karume [26] reported that occurrence of fungi in aerobic and anoxic activated sludge from MBRs (membrane bioreactors). Under aerobic condition, the Geotrichum was found at $(8.8 \%)$ followed by Penicillium (75.0\%), Yeasts (65.7\%) and Trichoderma (55.5\%), while Yeasts (77.1\%) Geotrichum candidum and Penicillium (61.1\%) species were the most prevalent in anoxic activated sludge. Showed by Kacprzak [27] study comparative analysis of fungal communities occurring in wastewater and sewage sludge. Additionally some physiochemical factors such as $\mathrm{pH}, \mathrm{BOD}$ and COD were determined. The $\mathrm{pH}$ values were generally neutral at the range from 6-7.85. The COD and BOD values of untreated waste water amounted from 202 to $618 \mathrm{mg} / \mathrm{dm}^{3}$ and 100 to $440 \mathrm{mg} / \mathrm{dm}^{3}$ respectively. The COD and BOD values of treated wastewater oscillated from 42 to $66 \mathrm{mg} / \mathrm{dm}^{3}$ and 10 to $40 \mathrm{mg} / \mathrm{dm}^{3}$, respectively. The comparative qualitative analysis showed that, most quantitative occurred genus Penicillium and usually occupied about $50 \%$ in all studied communities, occupied yeast $30 \%$ in untreated wastewater, $13 \%$ in treated wastewater and $19 \%$ in sewage sludge [21] observed reduction in COD rates oscillated from $86-92 \%$ in 21 days when treatment olive black water by using Aspergillus oryzae. It was also found that the Penicillium corylophilum was capable of removing $94.40 \%$ of COD and $98.95 \%$ of turbidity of filtrate with minimum dose of inoculum of $10 \% \mathrm{v} / \mathrm{v}$ in domestic waste water treatment plant sludge $(1 \% \mathrm{w} / \mathrm{w})$ [28]. The percent removal of sulfate, nitrate, ammonia and phosphate in anaerobic reactor was more significant than aerobic reactor. For the presence of fungi that contain a group of extracellular enzymes that facilitate the biodegradation of phenolic compounds, dyes, and PAH (poly aromatic hydrocarbons), among others, through non-specific oxidation reactions [29]. A number of genera of protozoa have been identified in activated sludge such as Papadimitriou [17] reported that Aspidisca cicada and Vorticella microstsoma were correlated to BOD5 removal capacity, while Podophrya fixa could be used as an indicator of low effluent SS content. Further, Liang [30] stated that $78 \%$ of $\mathrm{NH}_{4}$ could be removed in the combined system of Chlorella vulgaris and Bacillus licheniformis, while $29 \%$ in single algae system and only $1 \%$ in single bacteria system. Approximately $92 \%$ of total phosphate was removed in the combined system, compared with $55 \%$ and $78 \%$ in single algae and bacteria system respectively. 


\section{Conclusions}

(1) Activity of aerobic treatment plants is more than that of anaerobic plants, where COD reduction by aerobic attained $69.2 \%$, while anaerobic plants reduced to $31.9 \%$.

(2) Reduction TSS by aerobic plants is greater than that of the anaerobic plants because of the abundant presence of zooplankton.

\section{References}

[1] Luz, E. B., and Yoav, B. 2008. "Recent Advances in Removing Phosphorus from Wastewater and Its Future Use with Activated Sludge." Water Research 38: 4222-46.

[2] Mino, T. 2007. "Microbial Selection of Pollutants Accumulating Bacteria in Activated Sludge Wastewater Treatment Processes for Enhanced Biological Removal.” Biochemistry (Moscow) 65 (3): 341-8.

[3] Mary, B. L., Petra, P., Martina, M., Toma, M., David, P., and John, S. 2006. "Polychlorinated Biphenyl (PCB)-Degrading Bacteria Associated with Trees in a PCB-Contaminated Site." Appl. Environmental Microbiology 72: 2331-42.

[4] Mauro, T., Sandro, P., Dittmar, H., and Peduzzi, R. 2003. "Spatio-Temporal Distribution of Phototrophic Sulfur Bacteria in the Chemocline of Meromictic Lake Cadagno (Switzerland)." Microbiology Ecology 43: 89-98.

[5] Tiwari, K. B., Shrestha, L. M., and Agrawal, V. P. 2007. "Abundance of Lactose Assimilating Yeasts from Nepalese Murcha (Yeastcake).” Int. J. Life Sci. 1: 1-5.

[6] Awad, M. F., and Kraume, M. 2010. "The Occurrence of Fungi in Activated Sludge from MBRs." International Journal of Chemical and Biological Engineering 3 (4): 180-3.

[7] Chatterjee, A. K. 2010. Water Supply Waste Disposal and Environmental Engineering. New Delhi: Khanna Publishers.

[8] Gerardi, M. 2003. The Microbiology of Anaerobic Digesters. New York: Wiley-Inter science.

[9] Kudo, R. 1977. Protozoology. New Delhi. 1172 pp.

[10] Desikachary, T. V. 1959. Cyanophyta Indian Council of Agricultural Research. New Delhi 686 pp.

[11] Edward, G. B., and David C. S. 2010. Freshwater Algae: Identification and Use as Bioindicators. Chippenham: Wilts.

[12] Felisberto, S. A., and Rodrigues, L. 2004. "Periphytic Desmids in Corumba', Goiás, Brazil: Genus Cosmarium
Corda." Braz. J. Biol. 64 (1): 1-2.

[13] Prescott, G. W. 1964. The Fresh-Water Algae. Iowa: William, C. Brown Co.

[14] Kurtzman, C. P., and Fell, J. W. 1998. The Yeast : a Taxonomic Study. Elsevier Science.

[15] Bennet, J. W., Wunch, K. G., and Fasion, B. D. 2008. Use of Fungi Biodegradation. Manual of Environmental Microbiology. Washington, DC.: ASM Press.

[16] Kurtzman, C. P., Fell, J. W., and Boekhout, T. 2011. The Yeasts: A Taxonomic Study. Elsevier Science.

[17] Papadimitriou, S., Kennedy, H., Kattner, G., Dieckmann, G. S., and Thomas, D. N. 2004. "Experimental Evidence for Carbonate Precipitation and CO2 Degassing During Sea Ice Formation, Geochim." Cosmochim. Acta 68: 1749-61

[18] Tabak, H., and Cooke, W. B. 1968. "The Effects of Gaseous Environments on the Growth And Metabolism of Fungi." The Botanical Review 34: 126-252.

[19] APHA. 1989. Standard Methods for the Examination of Water and Wastewater. New York: American Public Health Association.

[20] APHA. 1999. Standard Methods for the Examination of Water and Wastewater, Water Environment Federation. Washington, DC.

[21] Öztepe, C., and Yurt, M. 2011. "Biological Degradation of Olive Black Water by Aspergillus oryzae: A Pilot Plant Investigation Canadian." $J$. on Environmental, Construction and Civil Engineering 2 (3): 24-31.

[22] Irvine, R. L., Wilderer, P. A., and Flemming, H. C. 1997. "Controlled Unsteady State Processes and Technologies-An Overview." Water Science and Technology 35 (1): 1-10.

[23] Bitton, G. 1994. Wastewater Microbiology. New York: Wiley-Liss Publication pp. 150-155.

[24] Bitton, G. 2005. Wastewater Microbiology. New York: Wiley-Liss Publication pp. 230-237.

[25] Tizghadam, M., Dagot, C., and Baudu, C. 2008. "Wastewater Treatment in a Hybrid Activated Sludge Baffled Reactor." Journal of Hazardous Materials 154: 550-7.

[26] Jaouani, A., Guillén, F., Penninckx, M. J., Martínez, A. T., and Martínez, M. J. 2005. "Role of Pycnoporus coccineus Laccase in the Degradation of Aromatic Compounds in Olive Oil Mill Wastewater." Enzyme and Microbial Technology 36: 478-486.

[27] Jeon, C. O., and Park, J. M. 2000. "Enhanced Phosphorus Removal in a Sequencing Batch Reactor Fed with Glucose as a Sole Carbon Source." Water Res. 34: 2160-70. 
[28] Shrestha, B., and Sharma, A. P. 1995. Manual on Practical Pharmaceutical Microbiology.

[29] Usharani, K., and Lakshmana perumalsamy, P. 2010. "Bio-treatment of Phosphate from Synthetic Wastewater Using Pseudomonas sp YLW-7.” J. Appl. Sci. Environ 14
(2): 75-80

[30] Liang, S., Zhao, X., Yuan, W., Liu, S., Cheng, X., and Xiao, Z. 2013. "A Long-Term Global Land Surface Satellite, (GLASS) Dataset for Environment Studies.” Int. J. Digital Earth. 